\title{
The Effects of Herbs-Infused Water on Body Weight and Waist Circumference in Patients With Metabolic Syndrome
}

\author{
$1^{\text {st }}$ Astri Purwanti \\ Postgraduate Program of Nutrition \\ Sciences \\ Universitas Sebelas Maret \\ Surakarta, Indonesia \\ zoneaz3@gmail.com
}

\author{
$2^{\text {nd }}$ Sugiarto \\ Postgraduate Program of Nutrition \\ Sciences \\ Universitas Sebelas Maret \\ Surakarta, Indonesia \\ giarto_sppd@yahoo.co.id
}

\author{
$3^{\text {rd }}$ Dono Indarto \\ Postgraduate Program of Nutrition \\ Sciences, Department of Physiology \\ and Biomedical Laboratory, Faculty of \\ Medicine \\ Surakarta, Indonesia \\ dono@staff.uns.ac.id
}

\begin{abstract}
Adults with metabolic syndrome have higher risks to suffer non communicable diseases like diabetes mellitus and cardiovascular diseases. In daily life, some Indonesian communities have routinely drunk spices and herbs-infused water instead of drinking pure water. However, the efficacy of this mixed water for patients with metabolic syndrome has not been established. The aim of this study was therefore to evaluate the effects of herbs-infused water (HIW) on body weight and waist circumference in patients with metabolic syndrome. This study used a quasi-experiment with pre-posttests control group design. A number of 24 patients who had metabolic syndrome and visited to Cakranegara Health Centre was participated in this study. They were randomly divided into two groups: control group drank water as usual whilst treatment group drank water as usual $+250 \mathrm{ml}$ herbs-infused water for 14 days. Their body weight and waist circumference were measured before and after intervention. There were only 23 research participants who completed this study. Herbs-infused water contained $12,769 \mathrm{ppm}$ of total antioxidant activity. After 14 days treatment, the body weight mean $(56.7 \pm 9.3 \mathrm{~kg})$ in the treatment group reduced significantly, compared with body weight mean $(59.8 \pm 10.2 \mathrm{~kg})$ before treatment and $(68.1 \pm 18 \mathrm{~kg})$ in the control group. In addition, a slightly reduction of waist circumference occurred in the treatment group but not in the control group. In conclusion, regular drinking of $250 \mathrm{ml}$ herbs-infused water for 14 days is able to reduce by $3 \mathrm{~kg}$ body weight in patients with metabolic syndrome. This finding may provide an alternative nutrition therapy for metabolic syndrome in future.
\end{abstract}

Keywords- metabolic syndrome, body weight, waist circumference, herbs, infused water

\section{INTRODUCTION}

Global prevalence of metabolic syndrome is approximately a quarter or more than one billion of population [1] and $21.66 \%$ Indonesian people have metabolic syndrome [2]. In addition, 20-25\% adults with metabolic syndrome around the world have 3 times higher risk to suffer coronary heart disease [3]. Institute for Health Metrics and Evaluation (2017) also showed that stroke is the highest cause of death in Indonesia, followed by coronary heart disease and diabetes mellitus [4]
The diagnosis of metabolic syndrome mainly relies on the presence of central obesity and followed by two alternative disorders like hyperglycemia, hypertension, hypertriglyceridemia, or low High-Density Lipoprotein Cholesterol (HDL-C) levels [5]. Furthermore, International Diabetes Federation (IDF) and World Health Organization (WHO) confirmed that the main criterion for metabolic syndrome is waist circumference, which reflects to central obesity compared with two other criteria [6]. So far, measurement of waist circumference becomes an important predictor for cardiovascular diseases in adult people with metabolic syndrome [7]. Fat accumulation in adipose tissues induces oxidative stress, resulting in increases of proinflammatory cytokines such as interleukin (IL-1 and IL-6) and tumor necrosis factor (TNF- $\alpha$ ) and decreases of various adipocytokines including leptin, adiponectin and resistin, which are important factors in energy regulation. All together it will rise insulin resistance and develop into diabetes mellitus [8] [9].

Healthy lifestyle intervention is recently considered as more appropriate management of metabolic syndrome than pharmacological intervention in order to reduce the risk of coronary heart disease [10]. For example, consumption of herbs and herbal products has been investigated for its benefits for the improvement of several metabolic syndrome markers. Those natural products act as food supplements or functional foods since they content bioactive compounds, particularly natural antioxidants [1].

To achieve this goal, infused or detoxified water is one way to bring phytochemical compounds from fruits, vegetables and herbs entering the human body [11]. This method has been widely used and developed in the community, but lacking of scientific evidence. Basically, infused water can replace plain water to provide the daily requirement of body fluids for water hydration [12]. The other benefits provide some micronutrients and bioactive compounds such as carotenoids (vitamin A precursor), tocotrienols, tocopherols (vitamin E), ascorbic acid and polyphenols (flavones, flavanones, anthocyanins, isoflavones and catechins) [13]. Therefore, the aim of this study was to investigate the effects of herbs-infused water on body weight 
and waist circumference of patients with metabolic syndrome.

\section{MATERIALS AND METHOD}

\section{A. Study Design and Participant Selection}

A quasi-experimental study with pre-posttest control group design was conducted adult patients with metabolic syndrome for one month (February 2020). They were recruited from Cakranegara Primary Health Center, Mataram City, West Nusa Tenggara and fulfilled research criteria: aged between 18-60 years old and had normal activities. On the other hand, patients who were reported to have acute inflammatory conditions, took antioxidant supplements, got pregnant or breastfeeding, received insulin injection, smoked and consumed alcohol excluded from this study.

To diagnose metabolic syndrome, we collaborated with the general physician in that Primary Health Care and used the IDF criteria: waist circumference $\geqslant 90 \mathrm{~cm}$ (males) and $\geqslant 80 \mathrm{~cm}$ (females) with two or more other parameters: fasting blood glucose level $\geqslant 100 \mathrm{mg} / \mathrm{dl}$, blood pressure $\geqslant$ $130 / 85 \mathrm{mmHg}$, triglyceride level (TG) $\geqslant 150 \mathrm{mmHg}$, and HDL-C levels for men $\leqslant 40.0 \mathrm{mg} / \mathrm{dl}$ and for women $\leqslant 50$ $\mathrm{mg} / \mathrm{dl}$ or had history of dyslipidemia treatment. The Research and Ethics Committee at RSUD dr. Moewardi Surakarta, Central Java approved this study protocol and consent form.

The participants were divided into control and treatment groups. Herbs-infused water was given in treatment group for 14 days combined with dietary counseling, otherwise control group only received dietary counseling. Routine daily pure water consumption and activities were not intervened in both groups. Daily food intakes were recorded with exception in special days, for examples feast or fasting days.

\section{B. Data Collection and Statistical Analysis}

Firstly, all patients with metabolic syndrome were screened by personal interview and filled food record and physical activity short form questionnaires. Eligible patients were then measured their body weight and waist circumference, which were carried out in the morning of the beginning and end of this study. All data were processed using SPSS program for statistic version 17.0. Mean \pm standard deviation was used to present numeric data whilst frequency was for categorical data. Normality and homogeneity data were evaluated using Shapiro-Wilk and Lavene test respectively. To compare mean differences between before and after treatment in control and treatment groups, we used independent and paired t-tests for data with normal distribution or Mann Whitney and Wilcoxon tests for data with non-normal distribution. Finally, we considered a significant difference as $\mathrm{p}$ value $<0.05$.

\section{Herbs-Infused Water Preparation and Procedures}

Spices and herbs used in this study were $2.5 \mathrm{~g}$ coriander, $2 \mathrm{~g}$ cinnamon, $5 \mathrm{~g}$ ginger and $5 \mathrm{~g}$ turmeric, which were obtained from a local market in Bertais district. Firstly, all materials were washed with tap water whereas cleaned ginger and turmeric were peeled and sliced thinly. A combination of herbs were then brewed with $250 \mathrm{ml}$ hot water. After that, the herbs-infused water was allowed to cool at room temperature for at least 9 hours and poured into bottles. Some samples of herbs infused water were examined for antioxidant activity level at Pratama Chem-Mix Laboratory, Yogjakarta.

\section{RESULT}

\section{A. General Characteristic of Research Participants}

Twenty four adult with metabolic syndrome participated in this study but one research participant resigned at the end of the study. They were 23 total participants who divided into control $(n=11)$ and treatment $(n=12)$ groups. Table 1 showed that general characteristics of research participants in the treatment group were similar to the control group. Female was more dominant than male in both groups. Lower average of BMI was observed in research participants in the treatment group $(25.8 \pm 5.8 \mathrm{~kg} / \mathrm{m} 2)$, compared to their counterparts $(28.1 \pm 6.8 \mathrm{~kg} / \mathrm{m} 2)$. In addition, the majority of research participants in both groups had moderate physical activity.

\section{B. Effect of herbs-infused water on body weight and waist circumference}

Although body weight and waist circumference are a poor predictor for fat distribution, these anthropometric measurements remain important for assessing metabolic risk of clinical and epidemiology studies in developing countries including Indonesia. The participants weight before intervention did not diverse significantly between two groups $(p=0.09)$. On the contrary, there was significantly different on body weight after 14 days infused water consumption $(\mathrm{p}=0.024)$. Significant weight loss after intervention mainly occurred in treatment group $(\mathrm{p}=0.000)$.

The average waist circumference of participants at the beginning of the study was significantly different between two groups $(p=0.049)$. Furthermore, significant differences were also found in the mean waist circumference after treatment $(\mathrm{p}=0.005)$.

TABLE I. GENERAL CHARACTERISTIC OF RESEARCH PARTICIPANTS $(\mathrm{N}=23)$

\begin{tabular}{|l|c|c|c|}
\hline \multicolumn{1}{|c|}{ Variables } & $\begin{array}{c}\text { Treatment group } \\
(\mathbf{n = 1 2})\end{array}$ & $\begin{array}{c}\text { Control Group } \\
(\mathbf{n = 1 1})\end{array}$ & $\boldsymbol{p}$ \\
\hline Age (y) & $52.25 \pm 3.5$ & $50.73 \pm 3.1$ & $0.283^{\mathrm{a}}$ \\
\hline Sex & $1(8.3)$ & $2(18.2)$ & $0.493^{\mathrm{b}}$ \\
\hline Male & $11(91.7)$ & $9(81.8)$ & \\
\hline Female & $25.8 \pm 5.8$ & $28.1 \pm 6.8$ & $0.420^{\mathrm{a}}$ \\
\hline BMI(kg/m $\left.{ }^{2}\right)$ & $91.97 \pm 5.8$ & $98.6 \pm 9.3$ & $0.049^{\mathrm{a}}$ \\
\hline $\begin{array}{l}\text { Waist } \\
\text { Circumference }(\mathrm{cm})\end{array}$ & $90 \pm 0.0$ & $93.5 \pm 0.7$ & \\
\hline Male & $92.14 \pm 6.0$ & $99.8 \pm 9.8$ & \\
\hline Female & $3(25)$ & $2(18.2)$ & $0.732^{\mathrm{b}}$ \\
\hline Physical Activity & $8(66.7)$ & $8(72.7)$ & \\
\hline Mild & $1(8.3)$ & $1(9.1)$ & \\
\hline Moderate & \multicolumn{3}{|l}{} \\
\hline Severe &
\end{tabular}

a. Data are presented in $\mathrm{n}(\%)$ or mean $\pm \mathrm{SD}$. $\mathrm{a}=$ independent $\mathrm{t}$ test or $\mathrm{b}=$ Mann Whitney test. 
TABLE II. ANTIOXIDANT ACTIVITY IC50 OF HERBS INFUSED WATER

\begin{tabular}{|c|c|}
\hline Test & Results \\
\hline Antioxidant activity $\mathrm{IC}_{50}(\mathrm{ppm})$ & $12,769.22$ \\
\hline
\end{tabular}

TABLE III. CHANGES IN BODY WEIGHT BEFORE AND AFTER INTERVENTION IN PATIENTS WITH METABOLIC SYNDROME

\begin{tabular}{|c|c|c|c|c|}
\hline \multirow{2}{*}{ Group } & \multicolumn{2}{|c|}{ Body weight (kg) } & \multirow{2}{*}{$*$} & $p$ \\
\cline { 2 - 3 } & Before & After & & $0.000^{\mathrm{a}}$ \\
\hline Treatment & $59.8 \pm 10.2$ & $56.7 \pm 9.3$ & -3.1 & $0.212^{\mathrm{a}}$ \\
\hline Control & $69.6 \pm 18.1$ & $68.1 \pm 18.0$ & -1.5 & \\
\hline$p$ & $0.09^{\mathrm{b}}$ & $0.024^{\mathrm{b}}$ & & \\
\hline \multicolumn{5}{|c}{ b. $\mathrm{a}=$ Paired t-test $\mathrm{b}=$ Mann Whitney test }
\end{tabular}

TABLE IV. CHANGES IN WAIST CIRCUMFERENCE BEFORE AND AFTER INTERVENTION IN PATIENTS WITH METABOLIC SYNDROME

\begin{tabular}{|c|c|c|c|c|}
\hline \multirow{2}{*}{ Group } & \multicolumn{2}{|c|}{ Waist Circumference $(\mathrm{cm})$} & \multirow{2}{*}{$\Delta$} & \multirow{2}{*}{$p$} \\
\cline { 2 - 3 } & Before & After & & $0.118^{\mathrm{a}}$ \\
\hline Treatment & $91.97 \pm 5,8$ & $89.5 \pm 6,9$ & -2.5 & \\
\hline Male & $90 \pm 0.0$ & $86 \pm 0.0$ & -4.0 & \\
\hline Female & $92.14 \pm 6.0$ & $89.8 \pm 7.1$ & -2.3 & \\
\hline Control & $98.6 \pm 9,3$ & $99.9 \pm 9,1$ & +1.3 & $0.647^{\mathrm{a}}$ \\
\hline Male & $93.5 \pm 0.7$ & $90.0 \pm 5.7$ & -3.5 & \\
\hline Female & $99.8 \pm 9.8$ & $102.1 \pm 8.3$ & +2.3 & \\
\hline$p$ & $0.049^{\mathrm{b}}$ & $0.005^{\mathrm{b}}$ & & \\
\hline
\end{tabular}

c. $\mathrm{a}=$ paired $\mathrm{t}$-test $\mathrm{b}=$ independent $\mathrm{t}$-test

Consumption of infused water for 14 days did not show significant differences in waist circumference in the treatment group $(\mathrm{p}=0.118)$ or the control group $(\mathrm{p}=0.648)$.

\section{DISCUSSION}

Antioxidant activity in this study examined use a quantitative DPPH (2,2-diphenyl-1pikrilhidrazil) method. This method was to measure radical captured by antioxidant from a compound using UV-Vis Spectrophotometry and it expressed by IC50 (Inhibitory Concentration) value. In other words, IC50 value is the ability of compounds to reduce free radicals by $50 \%$. It categorized to three levels as follows: very strong if less than $50 \mathrm{ppm}$, strong 50-100 ppm, moderate 100-150 ppm, weak 151-200 ppm, very weak > $200 \mathrm{ppm}$ [14]. The smaller IC50 value indicates that sample is more active as an antioxidant. Although herbs infused water has antioxidant values classified as very weak, it still stronger than Manalagi or Rome Beauty fresh apple. Antioxidant IC50 value of Rome Beauty apples is 49,870.8 ppm [15], while Manalagi apples is 36,848.9 ppm [16].

The average waist circumference of participants was 95.2 centimeter with standard deviation 8.2 centimeter. After 14 days intervention, the waist circumference decreased by 2.47 $\mathrm{cm}$ in the treatment group, while in the control group it increased by $1.3 \mathrm{~cm}$. reduction in waist circumference in treatment group was followed by significant weight loss of $3.1 \mathrm{~kg}(\mathrm{p}=0,000)$. Previous studies have shown that regular consumption of cinnamon for 8 weeks by $3 \mathrm{~g}$ can reduce body weight and body mass index of type 2 diabetes mellitus patients [17]. Other studies on normal obese subjects by giving $4 \mathrm{~g}$ of cinnamon capsules for 56 days showed a decrease in BMI, but not significantly different [18]. Waist circumference can be the best predictor of oxidative stress, shown in a study of Awadallah et al. in subjects with large waist circumference showed significantly lower levels of antioxidant enzymes and GSH, thus higher levels of MDA and carbonyl protein [19].

Cinnamon can interfere lipogenic processes, regulate the expression of transcription factors and target genes directly involved in lipogenesis. Consequently, it enables molecular adaptation that can prevent an increase in circulating cholesterol levels and lipid accumulation in adipose and liver tissue [20]. Ginger extract can regulate glycogen and inhibit gluconeogenesis process. In addition, ginger increases significantly on glycogen content, especially in kidney, but not significant in liver and muscle glycogen [21].

In the other study, giving coriander powder of $2 \mathrm{~g} / \mathrm{day}$ for 40 days to hyperlipidemic subjects showed a reduction in BMI but not significant [22]. Linalool as a component of coriander is known to be able to reverse the profile of hyperlipidemia by modulating gene expression related to glucose metabolism, utilization of fatty acids and major lipogenic genes [23]. Curcumin in turmeric shows the inhibitory effect of adipocyte proliferation and differentiation as well as increased catabolism in adipose tissue [24]. A meta-analysis by Akbari et al. concluded that intake of curcumin in patients with metabolic syndrome had a significant effect in reducing BMI, waist circumference and leptin levels, and increasing adiponectin levels [25].

Herbs infused water in this study can be an alternative drink to help reducing body weight although it is not significant alleviate waist circumference in metabolic syndrome patients. A decline in weight and waist circumference in obese people through diet management and lifestyle regulation can improve other components metabolic syndromes [26]. Metabolic syndrome that controlled by weight and waist circumference loss can improve the prognosis of the disease in the future [27].

\section{CONCLUSION}

To summarize, regular consumption of $250 \mathrm{ml}$ herbsinfused water for 14 days is able to reduce by $3 \mathrm{~kg}$ body weight in patients with metabolic syndrome.

\section{ACKNOWLEDGMENT}

We gratefully thank the Head of Cakranegara Health Center in Mataram City West Nusa tenggara and all of the management and medical teams, as well as all of respondents who had participate in this study.

\section{REFERENCES}

[1] M. G. Saklayen, "The Global Epidemic of the Metabolic Syndrome," Curr. Hypertens. Rep., vol. 20, no. 12, pp. 1-8, 2018, doi: https://doi.org/10.1007/s11906-018-0812-z HYPERTENSION.

[2] E. H. Herningtyas and T. S. Ng, "Prevalence and distribution of metabolic syndrome and its components among provinces and ethnic groups in Indonesia," BMC Public Health, vol. 19, no. 1, pp. 1-12, 2019, doi: 10.1186/s12889-019-6711-7.

[3] M. Adel Bakir, K. Hammad, and K. Bagdadi, "Prevalence of metabolic syndrome and its components among type 2 diabetic mellitus Syrian patients according to NCEP-ATP III and IDF diagnostic criteria," Anthropol. Rev., vol. 82, no. 1, pp. 1-14, 2019, doi: 10.2478/anre-2019-0001.

[4] Institute for Health Metrics and Evaluation, "Indonesia," 2019. http://www.healthdata.org/indonesia (accessed Nov. 27, 2019). 
[5] T. Chalvon-Demersay et al., "A Systematic Review of the Effects of Plant Compared with Animal Protein Sources on Features of Metabolic Syndrome," J. Nutr., no. 3, p. jn239574, 2017, doi: 10.3945/jn.116.239574.

[6] Nam Han Cho (chair) et al., IDF Diadetes Atlas, Eighth edition 2017. 2017.

[7] J. Kaur, "A comprehensive review on metabolic syndrome," Cardiol. Res. Pract., vol. 2014, 2014, doi: 10.1155/2014/943162.

[8] M. Abdelaal, C. W. le Roux, and N. G. Docherty, "Morbidity and mortality associated with obesity," Ann. Transl. Med., vol. 5, no. 7, pp. 1-12, 2017, doi: 10.21037/atm.2017.03.107.

[9] T. S. Han and M. E. Lean, "A clinical perspective of obesity, metabolic syndrome and cardiovascular disease," JRSM Cardiovasc. Dis., vol. 5, p. 204800401663337, 2016, doi 10.1177/2048004016633371.

[10] J. L. Rochlani, Yogita; Pothineni, Naga Venkata; Kovelamudi Swathi and Mehta, "Metabolic syndrome: pathophysiology, management, and modulation by natural compounds," Ther. Adv. Vaccines, vol. 11, no. 8, pp. 215-225, 2017, doi: $10.1177 / 1753944717711379$

[11] K. Thiagarajah, M. K. Ong, L. K. Teh, and H. S. Lye, Plants Infused Water as Preferred Healthy Drinks. Elsevier Inc., 2019.

[12] Akhmad and Anggraini, Edisi Lengkap 101 Resep Miracle Infused Water. Yogyakarta: Citra Media Pustaka, 2014.

[13] R. Álvarez, H. Araya, R. Navarro-Lisboa, and C. L. de Dicastillo, "Evaluation of polyphenol content and antioxidant capacity of fruits and vegetables using a modified enzymatic extraction," Food Technol. Biotechnol., vol. 54, no. 4, pp. 462-467, 2016, doi: $10.17113 / \mathrm{ft}$ b. $54.04 \cdot 16.4497$.

[14] N. A. Nugrahani, "Perbedaan Uji Aktivitas Antioksidan Antara Ekstrak Buah Kiwi Dan Apel Secara in Vitro," Sci. J. Farm. dan Kesehat., vol. 10, no. 1, p. 90, 2020, doi: 10.36434/scientia.v10i1.252.

[15] D. D. Wahyuni, "Perbandingan aktivitas antioksidan pada buah ape segar Romebeauty dan produk olahan sari apel dengan metode ABTS," University of Muhammadiyah Malang, 2018.

[16] S. T. Purwanto, "Perbandingan aktivitas antioksidan pada buah apel Manalagi dan produk olahan sari apel Manalagi dengan metode ABTS," University of Muhammadiyah Malang, 2018.

[17] M. Vafa et al., "Effects of cinnamon consumption on glycemic status, lipid profile and body composition in type 2 diabetic patients," Int. J. Prev. Med., 2012
18] H. Hendarto, F. R. Sari, and C. Adhyanto, "Cinnamomum burmannii improves insulin serum level in the normal obese subjects: preliminary study," J. thee Med. Sci. (Berkala Ilmu Kedokteran), vol. 50, no. 01, pp. 70-77, 2018, doi: 10.19106/jmedsci005001201808.

[19] S. Awadallah et al., "Waist circumference is a major determinant of oxidative stress in subjects with and without metabolic syndrome," Diabetes Metab. Syndr. Clin. Res. Rev., vol. 13, no. 4, pp. 25412547, 2019, doi: 10.1016/j.dsx.2019.07.010.

[20] B. P. Lopes et al., "Cinnamon extract improves the body composition and attenuates lipogenic processes in the liver and adipose tissue of rats," Food Funct., vol. 6, no. 10, pp. 3257-3265, 2015, doi: 10.1039/c5fo00569h.

[21] S. Muliaty, "Majalah Kedokteran UKI 2018 Vol XXXIV No.1 Januari - Maret Artikel Asli Efek Jahe (," Maj. Kedokt. UKI 2018 Vol, vol. XXXIV, no. 1, 2018.

[22] F. Zeb et al., "Supplementation of garlic and coriander seed powder: Impact on body mass index, lipid profile and blood pressure of hyperlipidemic patients," Pak. J. Pharm. Sci., 2018.

[23] V. Prachayasittikul, S. Prachayasittikul, S. Ruchirawat, and V. Prachayasittikul, "Coriander (Coriandrum sativum): A promising functional food toward the well-being," Food Res. Int., vol. 105, pp. 305-323, 2018, doi: 10.1016/j.foodres.2017.11.019.

[24] T. Jin, Z. Song, J. Weng, and I. G. Fantus, "Curcumin and other dietary polyphenols: Potential mechanisms of metabolic actions and therapy for diabetes and obesity," Am. J. Physiol. - Endocrinol. Metab., vol. 314, no. 3, pp. E201-E205, 2018, doi: 10.1152/ajpendo.00285.2017.

[25] M. Akbari et al., "The effects of curcumin on weight loss among patients with metabolic syndrome and related disorders: A systematic review and meta- analysis of randomized controlled trials," Front. Pharmacol., vol. 10, no. JUN, pp. 1-13, 2019, doi: 10.3389/fphar.2019.00649.

[26] A. E. Rothberg et al., "Impact of weight loss on waist circumference and the components of the metabolic syndrome," BMJ Open Diabetes Res. Care, vol. 5, no. 1, pp. 3-8, 2017, doi: 10.1136/bmjdrc-2016000341

[27] E. Fisher et al., "Increase of body mass index and waist circumference predicts development of metabolic syndrome criteria in apparently healthy individuals with 2 and 5 years follow-up," Int. J. Obes., vol. 43, no. 4, pp. 800-807, 2019, doi: 10.1038/s41366-018-0312-x. 